\title{
Evaluation of dripper clogging using magnetic water in drip irrigation
}

\author{
Mojtaba Khoshravesh $^{1}$ - Sayyed Mohammad Javad Mirzaei ${ }^{2}$ ([) $\cdot$ Pooya Shirazi ${ }^{3} \cdot$ Reza Norooz Valashedi $^{1}$
}

Received: 4 October 2017 / Accepted: 10 May 2018 / Published online: 18 May 2018

(c) The Author(s) 2018

\begin{abstract}
This study was performed to investigate the uniformity of distribution of water and discharge variations in drip irrigation using magnetic water. Magnetic water was achieved by transition of water using a robust permanent magnet connected to a feed pipeline. Two main factors including magnetic and non-magnetic water and three sub-factor of salt concentration including well water, addition of 150 and $300 \mathrm{mg} \mathrm{L}^{-1}$ calcium carbonate to irrigation water with three replications were applied. The result of magnetic water on average dripper discharge was significant at $(P \leq 0.05)$. At the final irrigation, the average dripper discharge and distribution uniformity were higher for the magnetic water compared to the non-magnetic water. The magnetic water showed a significant effect $(P \leq 0.01)$ on distribution uniformity of drippers. At the first irrigation, the water distribution uniformity was almost the same for both the magnetic water and the non-magnetic water. The use of magnetic water for drip irrigation is recommended to achieve higher uniformity.
\end{abstract}

Keywords Calcium carbonate $\cdot$ Discharge $\cdot$ Distribution uniformity $\cdot$ Dripper clogging $\cdot$ Agricultural

\section{Introduction}

Due to the shortage of water resources, the use of available water and use of unusual water is the main objective in agriculture. Increasing population, higher profitable activity and upgraded standards have led to an increase in wars over the freshwater resources. Therefore, it needs to provide additional land for farming to increase food production in order to support the acceleration of population growth to use all sources of low-quality water. Application of saline water

Sayyed Mohammad Javad Mirzaei

javadmirzaee61@gmail.com

Mojtaba Khoshravesh

khoshravesh_m24@yahoo.com

Pooya Shirazi

pooya.shirazi.alian@stu.um.ac.ir

Reza Norooz Valashedi

rezanorooz@yahoo.com

1 Water Engineering Department, Sari Agricultural Sciences and Natural Resources University, Sari, Iran

2 Water Engineering Department, Faculty of Agriculture and Animal Science, University of Torbat-e Jam, Torbat-e Jam, Iran

3 Department of Irrigation of Drainage, Faculty of Agriculture, Ferdowsi University of Mashhad, Mashhad, Iran with high salinity is an increasing problem in agriculture. In such situation, drip irrigation systems require continuum maintenance. The most important problem and concern dealing with these systems is dripper clogging that inversely affects the uniformity of distribution of water.

Drip irrigation involves small drippers either located on the soil, with water discharge at a well-ordered rate (Elmaloglou and Diamantopoulos 2007; Elmaloglou and Malamos 2006; Wang et al. 2006). Low water request by root of plants preserves an appropriate equilibrium of water and air in soil. Plants grow well under favorable water-air equilibrium and even soil moisture (Cook et al. 2003). Melo et al. (2008) investigated the effects of magnesium and calcium carbonates on dripper clogging and water uniformity distribution in drip irrigation. They showed that the dripper clogging reduced the water uniformity distribution and increased the variation coefficient of drippers. Han et al. (2017) investigated the lateral flushing on the dripper clogging and showed that the coefficient of uniformity of drippers was increased from 11.6 to $67.4 \%$ compared with non-flushed treatment.

Limited or comprehensive dripper clogging causes lower water application uniformity and therefore declines crop production and irrigation efficiency (Nakayama and Bucks 1991). Bucks et al. (1982) classified the clogging hazard into three classes of chemical, physical and biological clogging. Chemical blockage is provided to 
sedimentation of calcium and carbonate that is common in arid provinces with waters rich in calcium and bicarbonates. Chemical clogging through salt precipitation is identical hard to be controlled.

Many experimental researches were performed on amendment of calcium carbonate precipitation by magnet device. To adjust water, magnet device can be used (Maheshwari and Grewal 2009; Kney and Parsons 2006).

The variations affected by the magnetic impact depend on several parameters, including power of magnetic field, path of magnetic field, time of magnetic contact, solution discharge and $\mathrm{pH}$ (Baker and Judd 1996; Chibowski et al. 2003; Gabrielli 2001; Marcus 1994; Parsons et al. 1997). Ghauri and Ansari (2006) stated that weak magnetic field caused increasing of water viscosity, which was followed by the robust hydrogen bonds under magnet field. Bogatin et al. (1999) showed that quality of irrigation water was improved with magnetic water.

Lundager Madsen (2004) stated that the magnetic field is able to vary the direction of proton spin and to interrupt dehydration occurrences by impeding the transmission of proton to the water bit (Parsons et al. 1997). Busch and Busch (1997) indicated that magneto hydrodynamic effects perhaps be answerable for statements that magnet devices are occasionally active for sediment control in water-using systems. Aali et al. (2009) investigated the dripper clogging by effect of acidification and magnetized water and showed that the dripper indexes such as $U_{\mathrm{c}}$ and Eu in acidification treatment were better than magnetized water. Sahin et al. (2012) evaluated the dripper clogging with magnetized saline water. They found that drippers discharge with magnetized water were higher than non-magnetized water. Shaker et al. (2014) stated that drippers discharge in magnetized water and non-magnetized water treatments were 3.75 and $3.46 \mathrm{~L} \mathrm{~h}^{-1}$, respectively.

The magnetic water had been investigated by many researches. There is little training about the investigation of magnetic water on water uniformity distribution in drip irrigation. The aim of this research was to study the effects of magnetic saline water on uniformity of distribution of water and variations of dripper discharge in drip irrigation.

\section{Materials and methods}

In this research, two subunits were applied and subunits had 9 laterals with length of $40 \mathrm{~m}$, spaced $1.5 \mathrm{~m}$ apart. All pipes were polyethylene. Drippers, set $1 \mathrm{~m}$ apart. The in-line, long-path, drippers with a discharge of $4 \mathrm{~L} \mathrm{~h}^{-1}$, were used. Totally 15 irrigations (IN: irrigation number) with intervals of 7 days were applied in Shiraz during the summer 2017. The average temperature was $30^{\circ} \mathrm{C}$. Irrigation was done for $4 \mathrm{~h}$. The schematic structure of irrigation treatment that was used in the field is presented in Fig. 1.

Two main treatments consist of non-magnetic irrigation $\left(W_{1}\right)$ and magnetic irrigation water $\left(W_{2}\right)$, and three subtreatments of salt concentration including control $0.0 \mathrm{mg} \mathrm{L}^{-1}$ $\left(S_{1}\right), 150 \mathrm{mg} \mathrm{L}^{-1}\left(S_{2}\right)$ and $300 \mathrm{mg} \mathrm{L}^{-1}$ calcium carbonate $\left(S_{3}\right)$ were used. The following notations were used for the measurements: $T_{1}, T_{2}, T_{3}, T_{4}$ and $T_{5}$ are for first irrigation, fourth irrigation, eighth irrigation, twelfth irrigation and fifteenth irrigation, respectively. Also, $L_{1}, L_{2}$ and $L_{3}$ are the drippers located at the start of lateral, the mid of lateral and the termination of lateral, respectively. The dripper discharge was measured by the volumetric method by separating the capacity of collected water under the dripper to the irrigation time
Fig. 1 The schematic of experimental system including the magnetic and non-magnetic sub-systems
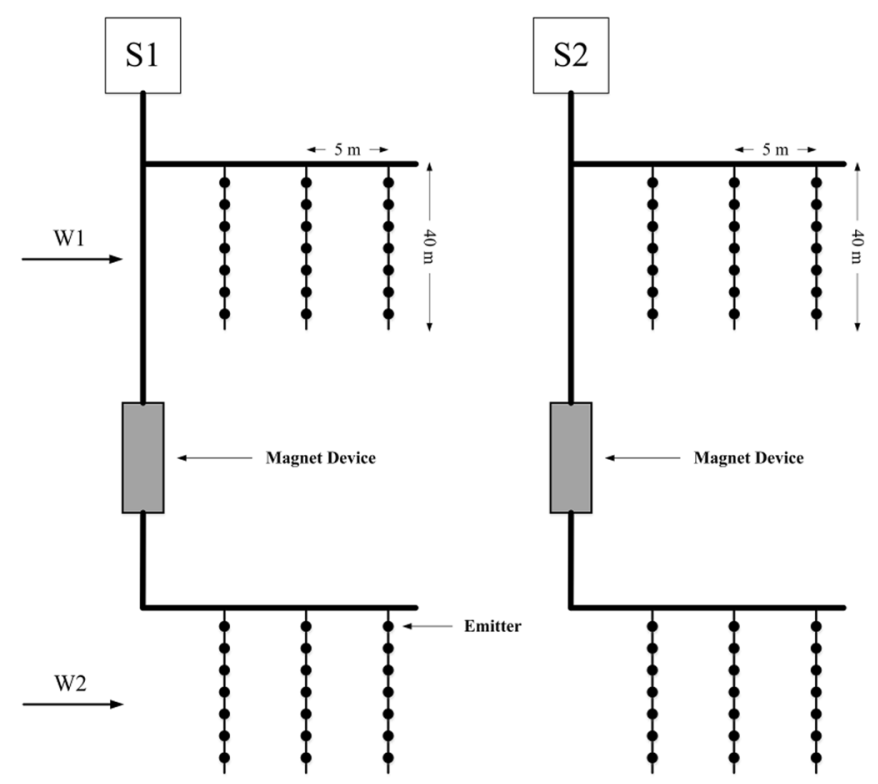

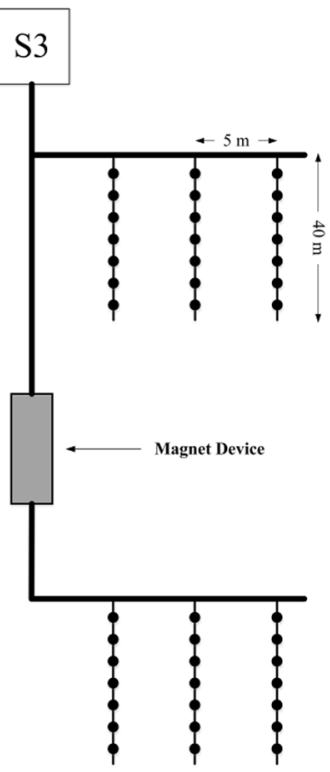


of three hours. The Langelier saturation index (LSI) was measured for all treatments to help in prediction of calcium carbonate precipitation. The water distribution uniformity $\left(D_{\mathrm{u}}\right)$, emission uniformity $(\mathrm{Eu})$, the Christiansen's coefficients of uniformity $\left(U_{\mathrm{c}}\right)$, dripper discharge average $\left(q_{\mathrm{a}}\right)$ and the dripper discharge variations $\left(q_{\mathrm{var}}\right)$ were determined using the equations given by Merriam and Keller (1978). Table 1 shows the mean values of irrigation water characteristics for dissimilar treatments.

Magnetic water was achieved by transition of water using a robust permanent magnet connected to a feed pipeline (Fig. 1).

The permanent magnets (ceramic magnets) with the trade name of Saba Poul (Sabaparsian, Tehran, Iran) were installed around the sub-main pipe before the water enters to the laterals. In the second method, the power requirement was 0.3 Tesla. The south and north poles were located on the top and the down of the pipe, respectively. The procedure of the north and the south poles and path of the formed magnet field are presented in Fig. 2 (Grewal and Maheshwari 2011).

\section{Results and discussion}

The result of magnetic water on the electrical conductivity (EC) and LSI of irrigation water was significant $(P \leq 0.05)$ (Table 2). The effects of water salinity and time of sampling on EC of irrigation water were significant $(P \leq 0.01)$. The interactive effect of magnetic water with time of sampling on the $\mathrm{EC}$ of water was significant $(P \leq 0.01)$. Similar results were achieved for the interactive effect of water salinity with time of sampling on the EC of water. The highest EC belonged to the water salinity of $300 \mathrm{mg} \mathrm{L}^{-1}$ calcium carbonate treatment (Table 3). The mean EC of the magnetic water was more than the non-magnetic water, and the difference was significant at the $5 \%$ level (Table 3). The mean LSI of the magnetic water was less than the non-magnetic water, and the difference was significant at the 5\% level (Table 3). Magnetic water resulted in less salts precipitate in pipe and higher irrigation water salts which cause higher water salinity. When the water passes from the magnet field its arrangement and some physical features will change (Higashitani et al. 1993). When the carbonate and calcium ions come into the area that is swayed by the magnets, they are pushed in opposed ways, due to their opposed charges. As all of the

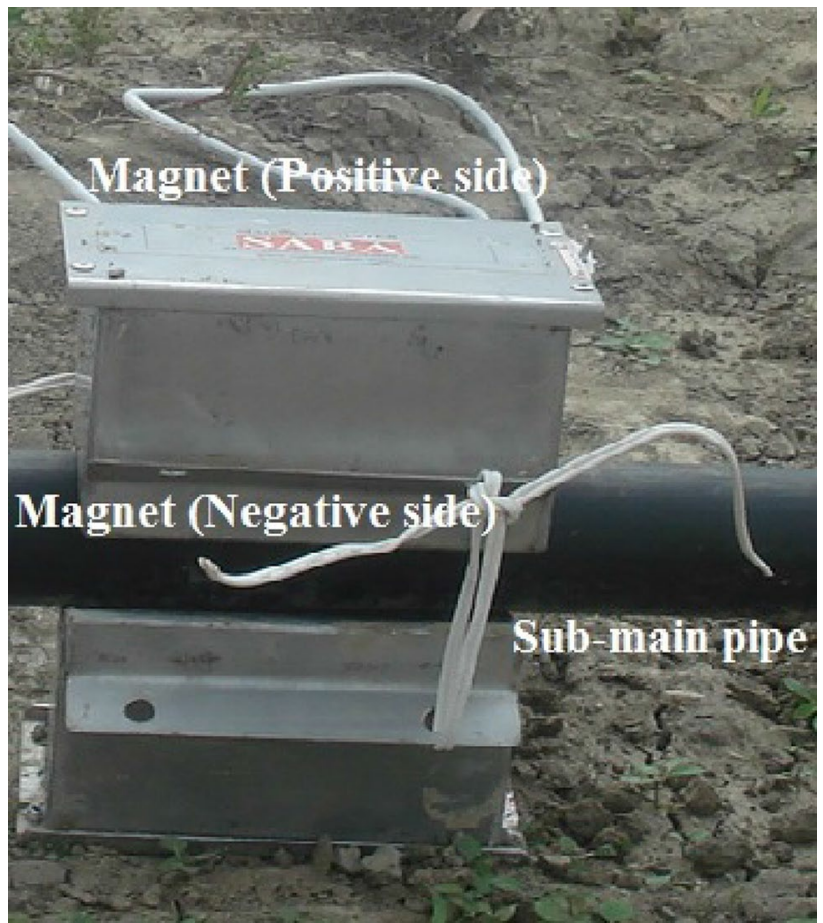

Fig. 2 Magnetic device with two permanent magnets showing their north and south poles

calcium ions were pushed in one path and all of the carbonate anions were pushed in the opposed direction, they have a tendency to collide. When these impacts occur, the ions stick together starting a solid system of calcium carbonate that was called aragonite. As these tiny crystals are enforced to form while moving in the water, they do not have chance to attach themselves to the pipelines. Therefore, the salts do not residue in the pipelines and cause higher EC.

By using magnetic water, the crystal growth accelerate reduced (Barrett and Parsons 1998; Higashitani et al. 1993). The change of scale can be a product from the special development of the aragonite polymorph (Knez and Pohar 2005; Kobe et al. 2001), instead of calcite. Aragonite, which may be a product from the change of metastable vaterite nuclei, exhibits specific needle form morphology with a fair adhesion to the substrate of the pipe (Fathi et al. 2006; Gabrielli et al. 1999).

With magnetic water, the contact angles are extenuated due to the increase of polarizing effect and the changes in

Table 1 The chemical characteristics of irrigation water for different treatments

\begin{tabular}{lllllllll}
\hline Treatments & $\mathrm{EC}(\mathrm{dS} / \mathrm{m})$ & $\mathrm{pH}$ & $\mathrm{Ca}(\mathrm{meq} / \mathrm{l})$ & $\mathrm{Mg}(\mathrm{meq} / \mathrm{l})$ & $\mathrm{Na}(\mathrm{meq} / \mathrm{l})$ & $\mathrm{HCO}_{3}(\mathrm{meq} / \mathrm{l})$ & $\mathrm{Cl}(\mathrm{meq} / \mathrm{l})$ & $\mathrm{SO} 4(\mathrm{meq} / \mathrm{l})$ \\
\hline$S_{1}$ & 0.58 & 7.6 & 2.92 & 2.11 & 1.42 & 3.13 & 1.26 & 2.11 \\
$S_{2}$ & 0.73 & 7.7 & 3.21 & 2.35 & 1.51 & 3.51 & 1.31 & 2.25 \\
$S_{3}$ & 1.01 & 7.8 & 3.74 & 2.59 & 1.58 & 4.27 & 1.38 & 2.32 \\
\hline
\end{tabular}


Table 2 Analysis of variance for the measured parameters of irrigation treatments

\begin{tabular}{|c|c|c|c|c|c|c|c|c|c|c|}
\hline \multirow[t]{2}{*}{ Parameter } & \multirow{2}{*}{$\begin{array}{l}\text { Degrees of } \\
\text { freedom }\end{array}$} & \multicolumn{9}{|c|}{ Mean squares } \\
\hline & & $\mathrm{EC}$ & $\mathrm{pH}$ & $\mathrm{Ca}$ & $\mathrm{Mg}$ & $\mathrm{Na}$ & $\mathrm{Cl}$ & $\mathrm{HCO}_{3}$ & $\mathrm{SO}_{4}$ & LSI \\
\hline$W$ & 1 & $0.066^{*}$ & $0.032^{\mathrm{ns}}$ & $0.026^{\mathrm{ns}}$ & $0.017^{\mathrm{ns}}$ & $0.041^{\mathrm{ns}}$ & $0.015^{\mathrm{ns}}$ & $0.039^{\mathrm{ns}}$ & $0.009^{\mathrm{ns}}$ & $0.072^{*}$ \\
\hline Error & 4 & 0.016 & 0.012 & 0.224 & 0.216 & 0.104 & 0.073 & 0.133 & 0.206 & 0.101 \\
\hline$S$ & 2 & $3.54^{* *}$ & $0.422^{\mathrm{ns}}$ & $47.55^{* *}$ & $0.037^{\mathrm{ns}}$ & $0.059^{\mathrm{ns}}$ & $0.038^{\mathrm{ns}}$ & $34.32^{* *}$ & $0.033^{\mathrm{ns}}$ & $3.82^{* *}$ \\
\hline$W \times S$ & 2 & $0.009^{\mathrm{ns}}$ & $0.007^{\mathrm{ns}}$ & $0.028^{\mathrm{ns}}$ & $0.010^{\mathrm{ns}}$ & $0.014^{\mathrm{ns}}$ & $0.008^{\mathrm{ns}}$ & $0.043^{\mathrm{ns}}$ & $0.025^{\mathrm{ns}}$ & $0.35^{*}$ \\
\hline Error & 8 & 0.022 & 0.011 & 0.357 & 0.064 & 0.053 & 0.039 & 0.198 & 0.051 & 0.072 \\
\hline$L$ & 2 & $0.007^{\mathrm{ns}}$ & $0.004^{\mathrm{ns}}$ & $0.073^{* *}$ & $0.044^{*}$ & $0.032^{*}$ & $0.023^{\mathrm{ns}}$ & $0.061^{* *}$ & $0.006^{\mathrm{ns}}$ & $0.009^{\mathrm{ns}}$ \\
\hline$W \times L$ & 2 & $0.006^{\mathrm{ns}}$ & $0.005^{\mathrm{ns}}$ & $0.009^{\mathrm{ns}}$ & $0.031^{\mathrm{ns}}$ & $0.0011^{\mathrm{ns}}$ & $0.021^{\mathrm{ns}}$ & $0.018^{\mathrm{ns}}$ & $0.007^{\mathrm{ns}}$ & $0.014^{\mathrm{ns}}$ \\
\hline$S \times L$ & 4 & $0.004^{\mathrm{ns}}$ & $0.005^{\mathrm{ns}}$ & $0.016^{\mathrm{ns}}$ & $0.003^{\mathrm{ns}}$ & $0.010^{\mathrm{ns}}$ & $0.018^{\mathrm{ns}}$ & $0.009^{\mathrm{ns}}$ & $0.013^{\mathrm{ns}}$ & $0.017^{\mathrm{ns}}$ \\
\hline$S \times W \times L$ & 4 & $0.003^{\mathrm{ns}}$ & $0.007^{\mathrm{ns}}$ & $0.008^{\mathrm{ns}}$ & $0.011^{\mathrm{ns}}$ & $0.013^{\mathrm{ns}}$ & $0.029^{\mathrm{ns}}$ & $0.016^{\mathrm{ns}}$ & $0.012^{\mathrm{ns}}$ & $0.009^{\mathrm{ns}}$ \\
\hline Error & 24 & 0.003 & 0.001 & 0.011 & 0.014 & 0.015 & 0.023 & 0.020 & 0.012 & 0.011 \\
\hline$T$ & 2 & $0.128^{* *}$ & $0.014^{\mathrm{ns}}$ & $3.94^{* *}$ & $0.769^{* *}$ & $0.342^{*}$ & $0.039^{\mathrm{ns}}$ & $2.83^{* *}$ & $0.317^{* *}$ & $0.016^{\mathrm{ns}}$ \\
\hline$W \times T$ & 2 & $0.018^{* *}$ & $0.006^{\mathrm{ns}}$ & $0.068^{* *}$ & $0.051^{*}$ & $0.011^{\mathrm{ns}}$ & $0.013^{\text {ns }}$ & $0.071^{* *}$ & $0.043^{*}$ & $0.009^{\mathrm{ns}}$ \\
\hline$S \times T$ & 4 & $0.023^{* *}$ & $0.007^{\mathrm{ns}}$ & $0.244^{* *}$ & $0.032^{\mathrm{ns}}$ & $0.026^{\mathrm{ns}}$ & $0.008^{\mathrm{ns}}$ & $0.030^{*}$ & $0.033^{*}$ & $0.01^{\mathrm{ns}}$ \\
\hline$S \times W \times T$ & 4 & $0.010^{\mathrm{ns}}$ & $0.007^{\mathrm{ns}}$ & $0.014^{\mathrm{ns}}$ & $0.012^{\mathrm{ns}}$ & $0.015^{\mathrm{ns}}$ & $0.006^{\mathrm{ns}}$ & $0.022^{\mathrm{ns}}$ & $0.021^{\mathrm{ns}}$ & $0.013^{\mathrm{ns}}$ \\
\hline$T \times L$ & 4 & $0.009^{\mathrm{ns}}$ & $0.005^{\mathrm{ns}}$ & $0.004^{\mathrm{ns}}$ & $0.027^{\mathrm{ns}}$ & $0.011^{\mathrm{ns}}$ & $0.019^{\mathrm{ns}}$ & $0.025^{\mathrm{ns}}$ & $0.016^{\mathrm{ns}}$ & $0.017^{\mathrm{ns}}$ \\
\hline$W \times T \times L$ & 4 & $0.012^{\mathrm{ns}}$ & $0.011^{\mathrm{ns}}$ & $0.018^{\mathrm{ns}}$ & $0.016^{\mathrm{ns}}$ & $0.013^{\mathrm{ns}}$ & $0.022^{\mathrm{ns}}$ & $0.019^{\mathrm{ns}}$ & $0.014^{\mathrm{ns}}$ & $0.021^{\mathrm{ns}}$ \\
\hline$S \times T \times L$ & 8 & $0.011^{\mathrm{ns}}$ & $0.0015^{\mathrm{ns}}$ & $0.013^{\mathrm{ns}}$ & $0.024^{\mathrm{ns}}$ & $0.017^{\mathrm{ns}}$ & $0.015^{\mathrm{ns}}$ & $0.026^{\mathrm{ns}}$ & $0.009^{\mathrm{ns}}$ & $0.038^{\mathrm{ns}}$ \\
\hline$S \times W \times T \times L$ & 9 & $0.003^{\mathrm{ns}}$ & $0.007^{\mathrm{ns}}$ & $0.014^{\mathrm{ns}}$ & $0.016^{\mathrm{ns}}$ & $0.013^{\mathrm{ns}}$ & $0.023^{\mathrm{ns}}$ & $0.019^{\mathrm{ns}}$ & $0.012^{\mathrm{ns}}$ & $0.009^{\mathrm{ns}}$ \\
\hline Error & 72 & 0.005 & 0.004 & 0.017 & 0.025 & 0.029 & 0.031 & 0.019 & 0.031 & 0.032 \\
\hline
\end{tabular}

*** and ns, represent significant at $5 \%$ level, significant at $1 \%$ level and nonsignificant, respectively. $W, S, L$ and $T$ represent type of irrigation water, irrigation water salinity, dripper location, and time of sampling, respectively

Table 3 The comparison of the mean values for the measured chemical parameters of irrigation water

\begin{tabular}{|c|c|c|c|c|c|c|c|c|c|c|}
\hline & Treatment & $\mathrm{EC}$ & $\mathrm{pH}$ & $\mathrm{Ca}$ & $\mathrm{Mg}$ & $\mathrm{Na}$ & $\mathrm{Cl}$ & $\mathrm{HCO}_{3}$ & $\mathrm{SO}_{4}$ & LSI \\
\hline \multirow[t]{2}{*}{$W$} & $W_{1}$ & $0.75^{\mathrm{b}}$ & $7.63^{\mathrm{a}}$ & $3.98^{\mathrm{a}}$ & $2.12^{\mathrm{a}}$ & $1.60^{\mathrm{a}}$ & $1.34^{\mathrm{a}}$ & $3.79^{\mathrm{a}}$ & $2.17^{\mathrm{a}}$ & $2.1^{\mathrm{a}}$ \\
\hline & $W_{2}$ & $0.88^{\mathrm{a}}$ & $7.60^{\mathrm{a}}$ & $3.89^{\mathrm{a}}$ & $2.14^{\mathrm{a}}$ & $1.55^{\mathrm{a}}$ & $1.36^{\mathrm{a}}$ & $3.71^{\mathrm{a}}$ & $2.19^{\mathrm{a}}$ & $0.3_{\mathrm{b}}$ \\
\hline \multirow[t]{3}{*}{$S$} & $S_{1}$ & $0.61^{\mathrm{c}}$ & $7.60^{\mathrm{a}}$ & $3.01^{\mathrm{c}}$ & $2.11^{\mathrm{a}}$ & $1.56^{\mathrm{a}}$ & $1.34^{\mathrm{a}}$ & $3.10^{\mathrm{c}}$ & $2.14^{\mathrm{a}}$ & $0.2^{\mathrm{c}}$ \\
\hline & $S_{2}$ & $0.79^{\mathrm{b}}$ & $7.66^{\mathrm{a}}$ & $3.85^{\mathrm{b}}$ & $2.10^{\mathrm{a}}$ & $1.62^{\mathrm{a}}$ & $1.38^{\mathrm{a}}$ & $3.69^{\mathrm{b}}$ & $2.12^{\mathrm{a}}$ & $0.9^{\mathrm{b}}$ \\
\hline & $S_{3}$ & $1.04^{\mathrm{a}}$ & $7.78^{\mathrm{a}}$ & $4.97^{\mathrm{a}}$ & $2.13^{\mathrm{a}}$ & $1.64^{\mathrm{a}}$ & $1.39^{\mathrm{a}}$ & $4.44^{\mathrm{a}}$ & $2.19^{\mathrm{a}}$ & $2.5^{\mathrm{a}}$ \\
\hline \multirow[t]{3}{*}{$L$} & $L_{1}$ & $0.81^{\mathrm{a}}$ & $7.69^{\mathrm{a}}$ & $4.00^{\mathrm{a}}$ & $2.15^{\mathrm{a}}$ & $1.62^{\mathrm{a}}$ & $1.38^{\mathrm{a}}$ & $3.80^{\mathrm{a}}$ & $2.20^{\mathrm{a}}$ & $1.6^{\mathrm{a}}$ \\
\hline & $L_{2}$ & $0.81^{\mathrm{a}}$ & $7.68^{\mathrm{a}}$ & $3.94^{\mathrm{b}}$ & $2.14^{\mathrm{a}}$ & $1.61^{\mathrm{a}}$ & $1.35^{\mathrm{a}}$ & $3.78^{\mathrm{a}}$ & $2.19^{\mathrm{ab}}$ & $1.7^{\mathrm{a}}$ \\
\hline & $L_{3}$ & $0.79^{\mathrm{a}}$ & $7.69^{\mathrm{a}}$ & $3.93^{\mathrm{b}}$ & $2.09^{\mathrm{b}}$ & $1.56^{\mathrm{b}}$ & $1.34^{\mathrm{a}}$ & $3.74^{\mathrm{b}}$ & $2.17^{\mathrm{b}}$ & $1.9^{\mathrm{a}}$ \\
\hline \multirow[t]{3}{*}{$T$} & $T_{1}$ & $0.85^{\mathrm{a}}$ & $7.70^{\mathrm{a}}$ & $4.16^{\mathrm{a}}$ & $2.22^{\mathrm{a}}$ & $1.69^{\mathrm{a}}$ & $1.40^{\mathrm{a}}$ & $3.95^{\mathrm{a}}$ & $2.23^{\mathrm{a}}$ & $1.5^{\mathrm{b}}$ \\
\hline & $T_{3}$ & $0.82^{\mathrm{b}}$ & $7.70^{\mathrm{a}}$ & $3.98^{\mathrm{b}}$ & $2.15^{\mathrm{b}}$ & $1.63^{\mathrm{b}}$ & $1.37^{\mathrm{ab}}$ & $3.79^{\mathrm{b}}$ & $2.18^{\mathrm{b}}$ & $1.7^{\circ}$ \\
\hline & $T_{5}$ & $0.77^{\mathrm{c}}$ & $7.68^{\mathrm{a}}$ & $3.71^{\mathrm{c}}$ & $2.03^{c}$ & $1.55^{\mathrm{c}}$ & $1.36^{\mathrm{b}}$ & $3.60^{c}$ & $2.10^{\mathrm{c}}$ & 2.0 \\
\hline
\end{tabular}

Each value in the table is an average of three replications distribution and clustering construction of water particles after magnetization. The extenuation of contact angles of magnetic water leads to increase the hydrophobic materials and decrease its surface tension force relative to that of well water, and thus its hydrophobicity decreases. As a result, it causes growth the solubility rule (Pang and Deng 2008). Bo et al. (2016) stated that dripper clogging control policy could be recognized according to suspended particles components in the same reclaimed water.
Table 4 shows the interaction effects of water irrigation and salinity water treatments on chemical parameters of irrigation water. The difference of LSI index between $S_{1}$, $S_{2}$ and $S_{3}$ under non-magnetic water and $S_{1}, S_{2}$ and $S_{3}$ under magnetic water was significant at 5 percent probability level. But the difference of other chemical parameters of irrigation water between $S_{1}, S_{2}$ and $S_{3}$ under non-magnetic water and $S_{1}, S_{2}$ and $S_{3}$ under magnetic water was not significant (Table 4). 
Table 4 The interaction effects of water irrigation and salinity water treatments on chemical parameters of irrigation water

\begin{tabular}{|c|c|c|c|c|c|c|c|c|c|c|c|c|c|c|c|c|c|c|}
\hline & \multicolumn{2}{|l|}{$\mathrm{EC}$} & \multicolumn{2}{|l|}{$\mathrm{pH}$} & \multicolumn{2}{|l|}{$\mathrm{Ca}$} & \multicolumn{2}{|l|}{$\mathrm{Mg}$} & \multicolumn{2}{|l|}{$\mathrm{Na}$} & \multicolumn{2}{|l|}{$\mathrm{Cl}$} & \multicolumn{2}{|c|}{$\mathrm{HCO}_{3}$} & \multicolumn{2}{|l|}{$\mathrm{SO}_{4}$} & \multicolumn{2}{|l|}{ LSI } \\
\hline & $W_{1}$ & $W_{2}$ & $W_{1}$ & $W_{2}$ & $W_{1}$ & $W_{2}$ & $W_{1}$ & $W_{2}$ & $W_{1}$ & $W_{2}$ & $W_{1}$ & $W_{2}$ & $W_{1}$ & $W_{2}$ & $W_{1}$ & $W_{2}$ & $W_{1}$ & $W_{2}$ \\
\hline$S_{1}$ & $0.55^{\mathrm{a}}$ & $0.75^{\mathrm{a}}$ & $7.62^{\mathrm{a}}$ & $7.61^{\mathrm{a}}$ & $3.1^{\mathrm{a}}$ & $2.95^{\mathrm{a}}$ & $2.07^{\mathrm{a}}$ & $2.15^{\mathrm{a}}$ & $1.61^{\mathrm{a}}$ & $1.51^{\mathrm{a}}$ & $1.29^{\mathrm{a}}$ & $1.39^{\mathrm{a}}$ & $3.28^{\mathrm{a}}$ & $2.92^{\mathrm{a}}$ & $2.11^{\mathrm{a}}$ & $2.17^{\mathrm{a}}$ & $0.25^{\mathrm{e}}$ & $0.15^{\mathrm{e}}$ \\
\hline$S_{2}$ & $0.68^{\mathrm{a}}$ & $0.90^{\mathrm{a}}$ & $7.63^{\mathrm{a}}$ & $7.69^{\mathrm{a}}$ & $4^{\mathrm{a}}$ & $3.7^{\mathrm{a}}$ & $2.05^{\mathrm{a}}$ & $2.15^{\mathrm{a}}$ & $1.69^{\mathrm{a}}$ & $1.55^{\mathrm{a}}$ & $1.30^{\mathrm{a}}$ & $1.46^{\mathrm{a}}$ & $3.75^{\mathrm{a}}$ & $3.63^{\mathrm{a}}$ & $2.08^{\mathrm{a}}$ & $2.16^{\mathrm{a}}$ & $1.02^{\mathrm{c}}$ & $0.78^{\mathrm{d}}$ \\
\hline$S_{3}$ & $0.93^{\mathrm{a}}$ & $1.15^{\mathrm{a}}$ & $7.80^{\mathrm{a}}$ & $7.50^{\mathrm{a}}$ & $5.05^{\mathrm{a}}$ & $4.89^{\mathrm{a}}$ & $2.09^{\mathrm{a}}$ & $2.17^{\mathrm{a}}$ & $1.70^{\mathrm{a}}$ & $1.58^{\mathrm{a}}$ & $1.32^{\mathrm{a}}$ & $1.46^{\mathrm{a}}$ & $4.56^{\mathrm{a}}$ & $4.32^{\mathrm{a}}$ & $2.10^{\mathrm{a}}$ & $2.28^{\mathrm{a}}$ & $3.02^{\mathrm{a}}$ & $1.98^{\mathrm{b}}$ \\
\hline
\end{tabular}

In each column and for each treatment, the values followed by at least one common character are not statistically different at 0.05 probability level

Fig. 3 Variations of dripper discharge during the experiment period

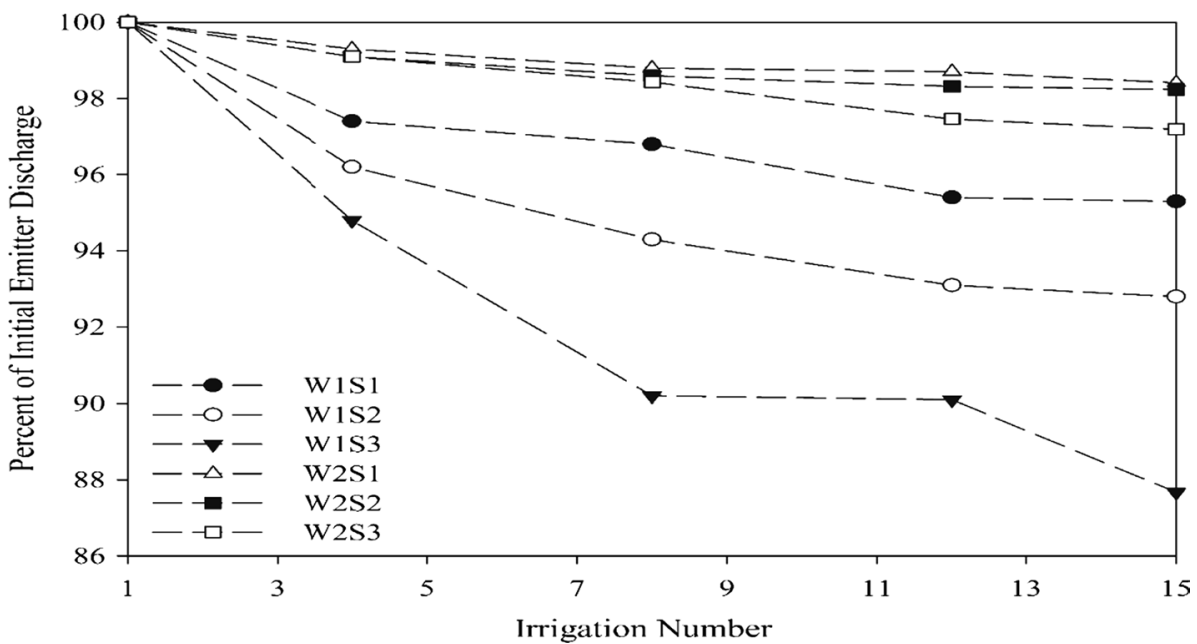

Figure 3 shows the comparison of changes of dripper discharge average for different treatments during the irrigation period. Our results presented that fewer variations in dripper discharge average occurred with the magnetic water (Fig. 3). At the first irrigation, there was no significant difference between the $W_{1} S_{1}$ and $W_{2} S_{1}$ treatments, but after the final irrigation, the difference between the above two treatments increased. For the $W_{1} S_{1}$ treatment, the reduction in dripper discharge average up to the final irrigation season was $4.7 \%$, while it was $1.59 \%$ for the $W_{2} S_{1}$ treatment. This shows that for the magnetic water, there was lower dripper discharge average during the experiment and there were less salt precipitations in the pipelines. For the $S_{2}$ and $S_{3}$ treatments, the reduction in dripper discharge average was higher during the irrigation term which shows that as the water salinity increases the salt precipitations also increase. For the $W_{1} S_{2}$ treatment, the reduction in dripper discharge average up to the final irrigation was $7.2 \%$, while it was $1.76 \%$ for the $W_{2} S_{2}$ treatment. The reduction in dripper discharge average up to the final irrigation for the $W_{1} S_{3}$ treatment was $12.33 \%$, while it was $2.81 \%$ for the $W_{2} S_{3}$ treatment. The highest reduction in dripper discharge average belonged to the $W_{1} S_{3}$ treatment and the lowest reduction in dripper discharge average belonged to the $W_{2} S_{1}$ treatment.

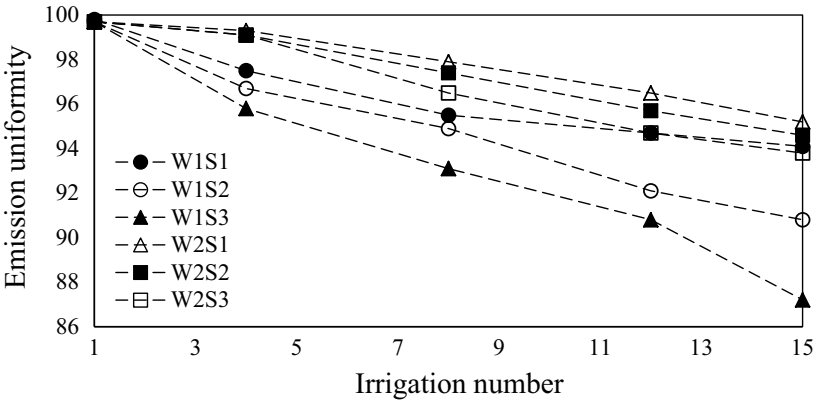

Fig. 4 Variations of emission uniformity during the experiment period

Figures 4, 5 and 6 show the changes of emission uniformity, Christiansen's coefficients of uniformity and distribution uniformity, respectively, for different treatments during the irrigation period. The results presented that fewer variations in dripper occurred with the magnetic water. At the first irrigation, there was no significant difference between the $W_{1} S_{1}$ and $W_{2} S_{1}$ treatments, but after the final irrigation, the difference between the above two treatments increased. For the $W_{1} S_{1}$ treatment, the reduction in emission uniformity up to the final irrigation season was $5.71 \%$, while it was $2.2 \%$ for the $W_{2} S_{1}$ treatment. For the $W_{1} S_{2}$ treatment, the reduction 


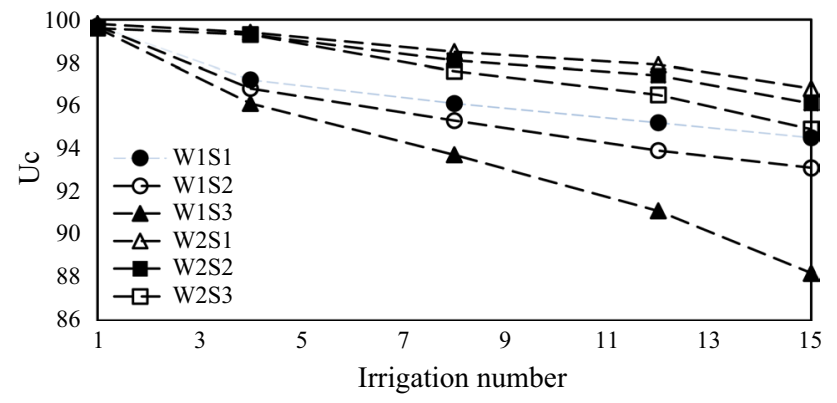

Fig. 5 Variations of Christiansen's coefficients of uniformity during the experiment period

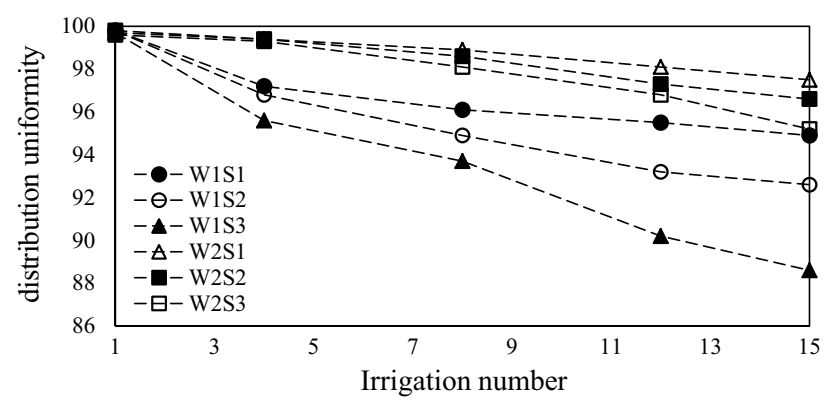

Fig. 6 Variations of distribution uniformity during the experiment period

in emission uniformity up to the final irrigation was $8.92 \%$, while it was $5.11 \%$ for the $W_{2} S_{2}$ treatment. The reduction in emission uniformity up to the final irrigation for the $W_{1} S_{3}$ treatment was $12.53 \%$, while it was $5.91 \%$ for the $W_{2} S_{3}$ treatment (Fig. 4).

For the $W_{1} S_{1}$ treatment, the reduction in Christiansen's coefficients of uniformity up to the final irrigation season was $5.21 \%$, while it was $3 \%$ for the $W_{2} S_{1}$ treatment. This was consistent with Han et al. (2017) findings, whose results concluded that the frequency increased, coefficient of uniformity decreased. For the $W_{1} S_{2}$ treatment, the reduction in Christiansen's coefficients of uniformity up to the final irrigation was $6.62 \%$, while it was $3.51 \%$ for the $W_{2} S_{2}$ treatment. The reduction in Christiansen's coefficients of uniformity up to the final irrigation for the $W_{1} S_{3}$ treatment was $11.44 \%$, while it was $4.71 \%$ for the $W_{2} S_{3}$ treatment (Fig. 5).

For the $W_{1} S_{1}$ treatment, the reduction in distribution uniformity up to the final irrigation season was $4.9 \%$, while it was $2.2 \%$ for the $W_{2} S_{1}$ treatment. For the $W_{1} S_{2}$ treatment, the reduction in distribution uniformity up to the final irrigation was $7.21 \%$, while it was $3.2 \%$ for the $W_{2} S_{2}$ treatment. The reduction in distribution uniformity up to the final irrigation for the $W_{1} S_{3}$ treatment was $11.13 \%$, while it was $4.41 \%$ for the $W_{2} S_{3}$ treatment (Fig. 6).

At the first irrigation, the dripper discharge average for the magnetic and non-magnetic water was the same, but at the final irrigation, this value for the magnetic water was more than the non-magnetic water which indicates less salt precipitate under magnetized condition. This result is agreement with the findings of Basher (2006).

Analysis of presented variance showed that the result of magnetic water and water salinity on dripper discharge average was significant $(P \leq 0.05)$ (Table 5). This table also shows that time of sampling, the interactive of irrigation water type with sampling and the interactive of water salinity with sampling on dripper discharge average were significant $(P \leq 0.01)$. The distribution uniformity for the non-magnetic water was less than magnetic water (Table 6). The decrease in distribution uniformity was advanced in higher irrigation water salinities. The highest difference in the reduction in the distribution uniformity between the magnetic water and the non-magnetic water occurred at water salinity of $300 \mathrm{mg} \mathrm{L}^{-1}$ calcium carbonate. This shows that the effect of magnetic water becomes higher as the irrigation water salt
Table 5 Analysis of variance for the parameters

\begin{tabular}{|c|c|c|c|c|c|c|}
\hline \multirow[t]{2}{*}{ Parameter } & \multirow{2}{*}{$\begin{array}{l}\text { Degree of } \\
\text { freedom }\end{array}$} & \multicolumn{5}{|c|}{ Mean squares } \\
\hline & & $q_{\mathrm{a}}$ & $\mathrm{Eu}$ & $U_{\mathrm{c}}$ & $D_{\mathrm{u}}$ & $q_{\mathrm{var}}$ \\
\hline$W$ & 1 & $0.18 *$ & $70.11 * *$ & $14.12 * *$ & $11.28 * *$ & $82.14 * *$ \\
\hline Error & 4 & 0.01 & 1.18 & 0.53 & 0.42 & 1.45 \\
\hline$S$ & 2 & $0.19 *$ & $28.10 * *$ & $10.08 * *$ & $8.17 * *$ & $89.41 * *$ \\
\hline$S \times W$ & 2 & $0.04^{\mathrm{ns}}$ & $15.59 * *$ & $0.78^{\mathrm{ns}}$ & $0.39^{\mathrm{ns}}$ & $11.73^{\mathrm{ns}}$ \\
\hline Error & 8 & 0.02 & 0.39 & 0.31 & 0.44 & 5.98 \\
\hline$T$ & 4 & $0.46^{* *}$ & $152.6^{* *}$ & $53.8 * *$ & $49.14 * *$ & $413.5^{* *}$ \\
\hline$W \times T$ & 4 & $0.31 * *$ & $24.37 * *$ & $12.13 * *$ & $10.76^{* *}$ & $29.62 * *$ \\
\hline$S \times T$ & 8 & $0.27 * *$ & $11.09 * *$ & $4.63 * *$ & $3.95 * *$ & $15.03 * *$ \\
\hline$S \times W \times T$ & 8 & $0.01^{\mathrm{ns}}$ & $1.66^{\mathrm{ns}}$ & $0.23^{\mathrm{ns}}$ & $0.11^{\mathrm{ns}}$ & $6.19^{\mathrm{ns}}$ \\
\hline Error & 48 & 0.01 & 0.5 & 0.12 & 0.08 & 0.94 \\
\hline
\end{tabular}

*,** and ns, represent significant at 5 percent level, significant at 1 percent level and nonsignificant, respectively. $W$ represents type of irrigation water, $S$ is irrigation water salinity, and $T$ is time of sampling 
Table 6 Comparison of means of the parameters

\begin{tabular}{|c|c|c|c|c|c|c|}
\hline Treatments & & $q_{\mathrm{a}}$ & $\mathrm{Eu}$ & $U_{\mathrm{c}}$ & $D_{\mathrm{u}}$ & $q_{\mathrm{var}}$ \\
\hline \multirow[t]{2}{*}{$W$} & $W_{1}$ & $3.78^{\mathrm{b}}$ & $88.43^{\mathrm{b}}$ & $89.06^{\mathrm{b}}$ & $90.24^{\mathrm{b}}$ & $17.85^{\mathrm{a}}$ \\
\hline & $W_{2}$ & $3.84^{\mathrm{a}}$ & $92.26^{\mathrm{a}}$ & $94.83^{\mathrm{a}}$ & $94.94^{\mathrm{a}}$ & $15.08^{b}$ \\
\hline \multirow[t]{3}{*}{$S$} & $S_{1}$ & $3.87^{\mathrm{a}}$ & $92.32^{\mathrm{a}}$ & $94.98^{\mathrm{a}}$ & $95.07^{\mathrm{a}}$ & $14.76^{\mathrm{c}}$ \\
\hline & $S_{2}$ & $3.80^{\mathrm{ab}}$ & $89.42^{\mathrm{b}}$ & $91.50^{\mathrm{b}}$ & $92.62^{\mathrm{b}}$ & $16.34^{\mathrm{b}}$ \\
\hline & $S_{3}$ & $3.76^{\mathrm{b}}$ & $87.29^{c}$ & $86.86^{c}$ & $89.08^{c}$ & $18.30^{\mathrm{a}}$ \\
\hline \multirow[t]{5}{*}{$T$} & $T_{1}$ & $3.98^{\mathrm{a}}$ & $94.31^{\mathrm{a}}$ & $96.05^{\mathrm{a}}$ & $96.13^{\mathrm{a}}$ & $11.24^{\mathrm{a}}$ \\
\hline & $T_{2}$ & $3.94^{\mathrm{b}}$ & $93.62^{\mathrm{b}}$ & $94.65^{b}$ & $94.74^{\mathrm{b}}$ & $12.56^{\mathrm{b}}$ \\
\hline & $T_{3}$ & $3.86^{\mathrm{c}}$ & $92.05^{\mathrm{c}}$ & $91.79^{c}$ & $91.90^{c}$ & $15.21^{\mathrm{c}}$ \\
\hline & $T_{4}$ & $3.77^{\mathrm{d}}$ & $89.63^{\mathrm{d}}$ & $87.57^{\mathrm{d}}$ & $89.71^{\mathrm{d}}$ & $19.22^{\mathrm{d}}$ \\
\hline & $T_{5}$ & $3.65^{\mathrm{e}}$ & $87.01^{\mathrm{e}}$ & $85.16^{\mathrm{e}}$ & $87.48^{\mathrm{e}}$ & $24.10^{\mathrm{e}}$ \\
\hline
\end{tabular}

Each value in the table is an average of three replications

\begin{tabular}{|c|c|c|c|c|c|c|c|c|c|c|}
\hline & \multicolumn{2}{|l|}{$q_{\mathrm{a}}$} & \multicolumn{2}{|l|}{$\mathrm{Eu}$} & \multicolumn{2}{|l|}{$U_{\mathrm{c}}$} & \multicolumn{2}{|l|}{$D_{\mathrm{u}}$} & \multicolumn{2}{|l|}{$q_{\mathrm{var}}$} \\
\hline & $W_{1}$ & $W_{2}$ & $W_{1}$ & $W_{2}$ & $W_{1}$ & $W_{2}$ & $W_{1}$ & $W_{2}$ & $W_{1}$ & $W_{2}$ \\
\hline$S_{1}$ & $3.74^{\mathrm{a}}$ & $4^{a}$ & $90.11^{\mathrm{b}}$ & $94.53^{\mathrm{a}}$ & $93.16^{\mathrm{a}}$ & $96.8^{\mathrm{a}}$ & $94.32^{\mathrm{a}}$ & $95.82^{\mathrm{a}}$ & $16.51^{\mathrm{a}}$ & $13.01^{\mathrm{a}}$ \\
\hline$S_{2}$ & $3.69^{\mathrm{a}}$ & $3.91^{\mathrm{a}}$ & $87.51^{\mathrm{c}}$ & $91.33^{b}$ & $90.21^{\mathrm{a}}$ & $92.79^{\mathrm{a}}$ & $91.07^{\mathrm{a}}$ & $94.17^{\mathrm{a}}$ & $17.72^{\mathrm{a}}$ & $14.96^{\mathrm{a}}$ \\
\hline$S_{3}$ & $3.65^{\mathrm{a}}$ & $3.87^{\mathrm{a}}$ & $85.14^{\mathrm{d}}$ & $89.44^{c}$ & $85.19^{\mathrm{a}}$ & $88.53^{\mathrm{a}}$ & $87.89^{\mathrm{a}}$ & $90.27^{\mathrm{a}}$ & $19.77^{\mathrm{a}}$ & $16.83^{\mathrm{a}}$ \\
\hline
\end{tabular}

In each column and for each treatment, the values followed by at least one common character are not statistically different at 0.05 probability level
Table 7 The interaction effects of water irrigation and salinity water treatments on the dripper parameters increases. Similar results were found for other uniformity parameters such as the emission uniformity and the Christiansen's uniformity coefficients of the dripper discharge.

The dripper discharge variations for the magnetic water were lower than the non-magnetic water. The lowest dripper discharge variations belonged to the control treatment. Proceeding through the time, the dripper discharge average decreased. At the first irrigation, the distribution uniformity was almost the same for both the magnetic water and the non-magnetic water. At the final irrigation, the uniformity parameters of magnetic water were higher than non-magnetic water.

Table 7 shows the interaction effects of water irrigation and salinity water treatments on the dripper parameters. The difference of emission uniformity between $S_{1}, S_{2}$ and $S_{3}$ under non-magnetic water and $S_{1}, S_{2}$ and $S_{3}$ under magnetic water was significant at 5 percent probability level. But the difference of $q_{\mathrm{a}}, U_{\mathrm{c}}, D_{\mathrm{u}}$ and $q_{\mathrm{var}}$ between $S_{1}, S_{2}$ and $S_{3}$ under non-magnetic water and $S_{1}, S_{2}$ and $S_{3}$ under magnetic water was not significant (Table 4 ).

\section{Conclusions}

Magnetic water can improve irrigation performance in drip irrigation. Irrigation using magnetic water compared to the non-magnetic water increased the dripper discharge average which indicates less dripper clogging and high distribution uniformity. The results displayed that the dripper discharge average is influenced by type of irrigation water and water salinity. The magnetic water showed significant influence on average dripper discharge, uniformity of distribution of water, emission uniformity, and Christiansen's uniformity coefficients of the dripper discharge, and the dripper discharge variations. For the non-magnetic water treatments, the average reduction in distribution uniformity up to the final irrigation was $10 \%$, while it was $2 \%$ for the magnetic water treatment. Also, the average reduction in distribution uniformity up to the final irrigation for the non-magnetic water treatment was $6 \%$, while it was $2 \%$ for the magnetic water treatment. These results can be useful in solving the problems of dripper clogging with applied of saline water.

Acknowledgement This work has been financially supported by the vice-chancellor for research of University of Torbat-e Jam.

Open Access This article is distributed under the terms of the Creative Commons Attribution 4.0 International License (http://creativeco mmons.org/licenses/by/4.0/), which permits unrestricted use, distribution, and reproduction in any medium, provided you give appropriate credit to the original author(s) and the source, provide a link to the Creative Commons license, and indicate if changes were made. 


\section{References}

Aali KA, Liaghat A, Dehghanisanij H (2009) The effect of acidification and magnetic field on emitter clogging under saline water application. J Agric Sci 1(1):132-141

Baker JS, Judd SJ (1996) Magnetic amelioration of scale formation. Water Res 30(2):247-260

Barrett RA, Parsons SA (1998) The influence of magnetic fields on calcium carbonate precipitation. Water Res 32(3):609-612

Basher DA (2006) Evaluation of the effect of magnetizing water and seeds on crop production under open field. Unpublished M.Sc. thesis. University of Khartoum, Sudan

Bo Z, Yunkai L, Peng S, Tianzhi W, Yinguang J, Honglu L (2016) Formulation of an emitter clogging control strategy for drip irrigation with reclaimed water. Irrig Drain 65(4):451-460

Bogatin J, Bondarenko NP, Gak EZ, Rokhinson EE, Ananyev IP (1999) Magnetic treatment of irrigation water: experimental results and application conditions. Environ Sci Technol Am Chem Soc 33(8):1280-1285

Bucks DA, Nakayama FS, Warrick AW (1982) Principles, practices, and potentialities of drip irrigation. Adv Irrig 1:219-298

Busch KW, Busch MA (1997) Laborator studies on magnetic water treatment and their relationship to a possible mechanism for scale reduction. Desalination 109(2):131-148

Chibowski E, Hołysz L, Szcześ A (2003) Adhesion of in situ precipitated calcium carbonate in the presence and absence of magnetic field in quiescent conditions on different solid surfaces. Water Res 37(19):4685-4692

Cook F, Thorburn P, Fitch P, Bristow K (2003) WetUp: a software tool to display approximate wetting patterns from drippers. Irrig Sci 22(3-4):129-134

Elmaloglou S, Diamantopoulos E (2007) Wetting front advance patterns and water losses by deep percolation under the root zone as influenced by pulsed drip irrigation. Agric Water Manag 90(1-2):160-163

Elmaloglou S, Malamos N (2006) A methodology for determining the surface and vertical components of the wetting front under a surface point source, with root water uptake and evaporation. Irrig Drain 55(1):99-111

Fathi A, Mohamed T, Claude G, Maurin G, Mohamed BA (2006) Effect of a magnetic water treatment on homogeneous and heterogeneous precipitation of calcium carbonate. Water Res 40(10):1941-1950

Gabrielli C (2001) Magnetic water treatment for scale prevention. Water Res 35(13):3249-3259

Gabrielli C, Maurin G, Poindessous G, Rosset R (1999) Nucleation and growth of calcium carbonate by an electrochemical scaling process. J Cryst Growth 200(1-2):236-250

Ghauri SA, Ansari MS (2006) Increase of water viscosity under the influence of magnetic field. J Appl Phys AIP 100(6):066101

Grewal HS, Maheshwari BL (2011) Magnetic treatment of irrigation water and snow pea and chickpea seeds enhances early growth and nutrient contents of seedlings. Bioelectromagnetics 32(1):58-65

Han S, Li Y, Xu F, Sun D, Feng J, Liu Z, Wu R, Wang Z (2017) Effect of lateral flushing on emitter clogging under drip irrigation with yellow river water and a suitable method. Irrig Seas Drain. https ://doi.org/10.1002/ird.2193

Higashitani K, Kage A, Katamura S, Imai K, Hatade S (1993) Effects of a magnetic field on the formation of $\mathrm{CaCO} 3$ particles. J Colloid Interface Sci 156(1):90-95

Kney AD, Parsons SA (2006) A spectrophotometer-based study of magnetic water treatment: assessment of ionic vs. surface mechanisms. Water Res 40(3):517-524

Knez S, Pohar C (2005) The magnetic field influence on the polymorph composition of $\mathrm{CaCO} 3$ precipitated from carbonized aqueous solutions. J Colloid Interface Sci 281(2):377-388

Kobe S, Dražić G, McGuiness P, Stražišar J (2001) The influence of the magnetic field on the crystallisation form of calcium carbonate and the testing of a magnetic water-treatment device. J Magn Magn Mater 236(1-2):71-76

Lundager Madsen HE (2004) Crystallization of calcium carbonate in magnetic field in ordinary and heavy water. J Cryst Growth 267(1-2):251-255

Maheshwari BL, Grewal HS (2009) Magnetic treatment of irrigation water: its effects on vegetable crop yield and water productivity. Agric Water Manag 96(8):1229-1236

Marcus Y (1994) A simple empirical model describing the thermodynamics of hydration of ions of widely varying charges, sizes, and shapes. Biophys Chem 51(2-3):111-127

Melo RFD, Coelho RD, Teixeira MB (2008) Clogging of a commercial drippers by calcium and magnesium precipitates using four Langelier saturation indexes. Irriga. http://eurekamag.com/resea rch/030/573/clogging-commercial-drippers-calcium-magnesiumprecipitates-langelier-saturation-indexes.php. 22 Jun 2014

Merriam JL, Keller J (1978) Farm irrigation system evaluation: a guide for management. Utah State University, Logan

Nakayama FS, Bucks DA (1991) Water quality in drip irrigation: a review. Irrig Sci 12(4):187-192

Pang X, Deng B (2008) Investigation of changes in properties of water under the action of a magnetic field. Sci China Ser G Phys Mech Astron 51(11):1621-1632

Parsons SA, Wang B-L, Judd SJ, Stephenson T (1997) Magnetic treatment of calcium carbonate scale-effect of $\mathrm{pH}$ control. Water Res 31(2):339-342

Sahin U, Tunc T, Eroglu S (2012) Evaluation of CaCO3 clogging in emitters with magnetized saline waters. Desalin Water Treat 40:168-173

Shaker BA, Saeed AB, Ahmed Al-Khalifa BA (2014) Effect of magnetizing technology on the drip irrigation system hydraulic performance and emitter clogging. J Agri-Food Appl Sci 2(9):292-295

Wang F-X, Kang Y, Liu S-P (2006) Effects of drip irrigation frequency on soil wetting pattern and potato growth in North China Plain. Agric Water Manag 79(3):248-264

Publisher's Note Springer Nature remains neutral with regard to jurisdictional claims in published maps and institutional affiliations. 